\title{
Burden of diarrhea among children in Honduras, 2000-2004: estimates of the role of rotavirus
}

\author{
José Orlando Solórzano Girón, ${ }^{1}$ Ida Berenice Molina, ${ }^{1}$ Reina M. Turcios-Ruiz, ${ }^{2}$ \\ Claudia E. Quiroz Mejia, ${ }^{1}$ Luis Miguel Amendola, ${ }^{3}$ Lucia Helena de Oliveira, ${ }^{4}$ \\ Jon K. Andrus, ${ }^{4}$ Paul W. Stupp, ${ }^{2}$ Joseph S. Bresee, ${ }^{2}$ and Roger I. Glass ${ }^{2}$
}

ABSTRACT Objectives. To estimate the annual burden of diarrhea and of diarrhea that is associated with rotavirus $(R V)$ in children who are treated at public clinics and hospitals in Honduras. Methods. Data were collected from computerized records of all children $<5$ years old treated for diarrhea at clinics and hospitals operated by the Secretary of Health for the period of 2000 through 2004. A review of studies of $R V$ in Honduras and neighboring countries provided estimates of detection rates of $R V$ among children treated for acute diarrhea as outpatients or as inpatients. From these data, we estimated the annual number of cases of diarrhea and of rotavirus-related diarrhea in Honduras, the cumulative incidence of diarrhea and of rotavirus-related diarrhea for a child from birth to age 5 years, and the number of fatalities due to $R V$ among children hospitalized for diarrhea.

Results. From 2000 through 2004, a mean of 222000 clinic visits, 4390 hospitalizations, and 162 in-hospital deaths due to diarrhea were recorded annually among children $<5$ years of age in the public health facilities in Honduras. From our review of scientific literature on Honduras and neighboring countries, an estimated $30 \%$ of outpatients and $43 \%$ of inpatients who were treated for diarrhea would be expected to have RV. Consequently, we estimated that 66600 outpatient visits, 1888 hospitalizations, and 70 in-hospital deaths among children $<5$ years in Honduras could be attributed to $R V$ each year. Therefore, a child in the first five years of life has a respective risk for consultation, hospitalization, and in-hospital death of 1:1, 1:46, and 1:1 235 for diarrhea. For an episode associated with $R V$, the respective risks are 1:3, 1:106, and 1:2 857. These values likely underestimate the true burden of diarrhea in Honduras, since some $51 \%$ of children with acute diarrhea do not receive formal care for the illness, $70 \%$ do not receive oral rehydration solution, and $80 \%$ of diarrheal deaths occur outside of hospitals.

Conclusions. Diarrhea is a major cause of illness among children $<5$ years old in Honduras, and $R V$ is likely the most common cause. Our preliminary estimates need to be refined so that health planners in Honduras can make decisions on the future use of rotavirus vaccines. A program of hospital-based surveillance for rotavirus in Honduras has been established to address this need.

Key words Diarrhea; rotavirus infections; health care costs; child, preschool; infant; infant, newborn; Honduras.

Secretaría de Salud, Tegucigalpa, Honduras.

2 Centers for Disease Control and Prevention, Atlanta, Georgia, United States of America. Send correspondence to: Reina M. Turcios-Ruiz, Centers for Disease Control and Prevention, 4770 Buford Highway, Mail Stop K-23, Atlanta, GA 30341, United States of America; telephone: 770-488-6219; fax: 770-488-6242; e-mail: RTurcios@cdc.gov
Pan American Health Organization, Tegucigalpa, Honduras.

4 Pan American Health Organization, Washington, D.C., United States of America. 
Diarrhea is a leading cause of illness and death among children in developing countries, and rotavirus (RV) is the most common etiologic agent (1). Consequently, the recent licensure of two new vaccines raises the prospect that this major childhood illness could soon be preventable (2). One RV vaccine, Rotarix (GlaxoSmithKline Biologicals, Rixensart, Belgium), which is administered in three doses (3), was first licensed in more than 10 Latin American countries during 2004 or 2005..$^{5}$ In addition, Rotarix will soon become part of Brazil's routine national immunization program (4). A second vaccine, RotaTeq (Merck and Company, Whitehouse Station, New Jersey, United States of America), which is administered in two doses (5), has been licensed in the Europe, Mexico, and the United States of America, and it could soon be available for more widespread use $(6,7)$. The ability of these potentially life-saving vaccines has raised the need for countries to fully assess the burden of the disease in their own settings so that they can determine the value of the vaccine there, as well as the cost at which vaccine introduction would be within their reach.

RV vaccines will likely be introduced in the Americas before distribution in other regions of the world (8). Rotarix is already sold in the private markets of some Latin American countries for as much as US\$ 50 per dose (9), bringing the total cost of a full course of this vaccine to US\$ 150 per child. However, the final cost of the vaccines has not been determined, and the true impact of the vaccines on severe and fatal disease will not be appreciated until the vaccine enters routine childhood immunization programs in these countries. Honduras is one of the six poorest countries in Latin America, with a per capita income below US\$ 1000 annually, but investment in health care is a national priority, and vaccine coverage rates

\footnotetext{
5 Vesikari T. RIX4414: a new attenuated human rotavirus vaccine [conference presentation abstract]. Available from: http://www.kenes.com/espid 2005/program/abstracts/487.doc.
}

are high (>90\%) (10). Honduras is also an early adopter of new vaccines, and it was one of the first in Latin America to successfully introduce a pentavalent vaccine against diphtheria, tetanus, pertussis, hepatitis B, and Haemophilus influenzae type b (Salvador Garcia, Pan American Health Organization, Washington, D.C., personal communication, 22 January 2004). The successful introduction of new vaccines, high immunization rates, and low per capita income make Honduras eligible for financial support for new vaccine introduction through the Global Alliance for Vaccines and Immunizations (GAVI) and the Vaccine Fund (11). GAVI is a partnership of both national and international public and private organizations, including UNICEF, the World Health Organization (WHO), the World Bank, pharmaceutical companies that manufacture vaccines, national ministries of health, nongovernmental organizations, and private donors, that aims to increase access to vaccines in developing countries. The Vaccine Fund is the financing resource created by the GAVI partners to support GAVI's goal. If there were a substantial burden of RV disease in Honduras, the country would be a good candidate for the early introduction of an RV vaccine, provided that the cost could be met with local resources. However, solid evidence from Honduras is needed in order to document the burden of RV disease and to estimate the cost-effectiveness of a vaccination program for the country.

In Honduras, Government hospitals and clinics provide most treatment for diarrhea diseases (10). The introduction of a vaccine could therefore have a measurable impact on outcomes that are routinely monitored by the Office of the Secretary of Health (Secretaría de Salud) (OSH).

To assess the burden of RV disease in Honduras, we reviewed surveillance data compiled by the $\mathrm{OSH}$ on hospitalizations, clinic visits, and deaths due to diarrhea. We linked this information with data on the rates of $\mathrm{RV}$ detection that might be expected among children with diarrhea seen in these settings. We concluded by estimating the burden of RV disease, in anticipation of more comprehensive data that will be coming in one to two years from a national sentinel hospital surveillance program that has been established at six hospitals throughout the country.

\section{METHODS}

To estimate the burden of childhood diarrhea leading to clinic visits, hospitalizations, and deaths, we reviewed the computerized records of the $\mathrm{OSH}$ on hospitalizations and clinic visits for diarrhea among children $<5$ years old for the years 2000 through 2004 . Using that data, we calculated the mean number of medical consultations, hospitalizations, and in-hospital deaths annually. We collected data on diarrhea-related events from four sources (Table 1). Visits for acute gastroenteritis to all public clinics $(N \approx$ $1200)$ and all public hospitals $(N=28)$ were obtained from the $\mathrm{OSH}$, which funds and provides care to approximately $60 \%$ of the population of Honduras (10). The OSH has traditionally divided public health infrastructure in the eighteen political divisions (departments) of the country into eight health regions, each encompassing several departments, and one metropolitan region, which is the capital and largest city, Tegucigalpa (10). Each public clinic and hospital regularly reports the number of visits and hospitalizations for diarrhea by age group to the OSH. Deaths occurring in hospitals are recorded in discharge records, which are regularly reviewed and compiled.

Additional mortality data were obtained from the 2001 National Survey of Epidemiology and Family Health (NSEFH 2001) (Encuesta Nacional de Epidemiología y Salud Familiar) (12). As part of NSEFH 2001, a total of 3936 mothers of children $<5$ years of age were interviewed between 21 February and 19 August of 2001, about their children's health, immunization history, and symptoms and treatment for diarrheal episodes in the preceding 
TABLE 1. Sources of data on diarrhea-related events among Honduran children $<5$ years old

\begin{tabular}{lll}
\hline \multicolumn{1}{c}{ Event } & \multicolumn{1}{c}{ Source of data $^{a}$} & \multicolumn{1}{c}{ Reporting unit } \\
\hline Consultations $^{b}$ & Logs of weekly clinic visits & All public clinics $(N \approx 1200)$ \\
Hospitalizations $^{b}$ & Reports of monthly hospital discharges & All public hospitals $(N=28)$ \\
In-hospital deaths & Hospital records & All public hospitals $(N=28)$ \\
Deaths & National survey & Mothers of children $<5$ years \\
& & $(n=3936)$
\end{tabular}

a Secretaría de Salud, Honduras.

b 60\% of the population in Honduras receives care in public facilities (10).

c 15\% of all deaths are reported through hospital discharges $(16,17)$.

15 days. The women were selected systematically: One woman of childbearing age with children $<5$ years old living in the household was selected from 12000 households in 400 randomly selected census tracts (30 households per tract). The selected census tracts were located throughout Honduras, except for a sparsely populated, remote eastern department (Gracias a Dios) and the department (Islas de la Bahia) that is composed of three small islands in the Caribbean Sea. Responses were weighted by the number of children $<5$ years old in the household. If it was found that a child had died, the circumstances surrounding the death were explored. Among the questions were whether a death certificate had been obtained, and if the death had been registered with civil authorities.

To determine the likelihood that a diarrhea event was caused by RV, we developed estimates from two studies that examined RV diarrhea in Honduras, and we compared these results with findings from other studies in the Latin America. One community-based study in Honduras followed 268 children $<5$ years of age for diarrhea episodes over the course of a year. RV was detected in $15 \%$ of children who developed diarrhea, and it was observed most frequently from November to March in children $\geq 13$ months of age (13). In the second Honduran study (14), children with diarrhea who were seen in an emergency room over a 24-month period were enrolled in a trial evaluating Saccharomyces boulardii for the treatment of acute diarrhea. RV was detected in $43 \%$ of samples tested from 521 children $<5$ years old. A recent review of selected studies of RV in Latin America yielded a median detection rate of $30 \%$ among children in the outpatient setting and of $38 \%$ among children who were hospitalized with more severe disease (15). From these data we extrapolated RV detection rates of $30 \%$ for outpatients (15) and of $43 \%$ for inpatients (13). We multiplied these figures by the mean annual number of clinic visits and hospitalizations derived from the Honduran data. To calculate the deaths attributable to RV, we applied the RV estimate for severe cases leading to hospitalization (43\%) to the number of diarrheal deaths each year in Honduras extrapolated by two methods. Since only approximately $15 \%$ of all deaths are reported through hospital discharge records $(16,17)$, we first estimated the total number of deaths due to diarrhea by dividing the number of in-hospital deaths due to diarrhea by 0.15 . The second method that we used to estimate the overall burden of diarrheal disease was developed by Parashar et al. (1). The method took the number of deaths among children $<5$ years, which was estimated by multiplying the mortality rate of those $<5$ years old (48/1 000 live births (18)) by the mean size of an annual birth cohort $(N \approx 200000(18))$. This number was then multiplied by 0.17 , for the $17 \%$ of those deaths attributable to di- arrhea, in line with the country's per capita gross national product (1).

We calculated the cumulative risks of a diarrhea-related and of a rotavirusrelated event per child from birth to age 5 years. To derive this risk, we assumed that the number of all diarrhearelated or rotavirus-related events that would occur in a single year among a group of children $<5$ years old would be equal to the number of events occurring in a one-year birth cohort of children followed to age 5. We expressed each cumulative risk as the ratio of one to the average size of a oneyear birth cohort divided by the number of specific events (consultations, hospitalizations, and deaths). The $\mathrm{cu}$ mulative risk of diarrhea-related consultation, for example, was expressed as one to the quotient of the average birth cohort and the average number of diarrhea-related consultations in one year.

Finally, to examine the seasonality of diarrhea-related events, we plotted the monthly number of consultations and hospital discharges among children $<5$ years of age as a function of time, and we calculated and graphed the median number of events per year. We shaded the portions of the curve that met two criteria suggestive of a "RV season": (1) where for a period of two or more months the number of consultations and hospitalizations exceeded the annual median and (2) that occurred between November and March, the period of the year when RV has been documented to circulate in Honduras and in neighboring countries $(13,19-21)$.

\section{RESULTS}

From 2000 to 2004, OSH computerized records for public facilities identified a mean of 222000 consultations annually for diarrhea among children < 5 years old (range: 196100 to 247 169), 4390 hospital discharges (range: 3809 to 5513), and 162 inhospital deaths (range: 38 to 182) (Table 2). Studies in Latin America and Honduras reported RV detection rates 
TABLE 2. Mean diarrhea-related events per year reported by public facilities among Honduran children $<5$ years old for 2000-2004, estimated rotavirus (RV)-related events, and calculated cumulative risks for diarrhea- and rotavirus-related consultations, hospitalizations, and deaths per child by age 5 years

\begin{tabular}{lccccc}
\hline \multicolumn{1}{c}{ Event } & $\begin{array}{c}\text { Mean diarrhea-related } \\
\text { events/year }\end{array}$ & $\begin{array}{c}\text { RV detection rate } \\
\text { (reference) }\end{array}$ & $\begin{array}{c}\text { Estimated RV-related } \\
\text { events/year }\end{array}$ & $\begin{array}{c}\text { Risk of diarrhea-related } \\
\text { event by a Honduran } \\
\text { child by age 5 } 5^{\mathrm{a}}\end{array}$ & $\begin{array}{c}\text { Risk of RV-related } \\
\text { event by a Honduran } \\
\text { child by age 5a }\end{array}$ \\
\hline Consultations & 222000 & $30 \%(15)$ & 66600 & $1: 1$ & $1: 3$ \\
Hospitalizations & 4390 & $43 \%(14)$ & 1888 & $1: 46$ & $1: 106$ \\
In-hospital deaths & 162 & $43 \%(14)$ & 70 & $1: 1235$ & $1: 2857$ \\
Total deaths (method 1) & 1080 & $43 \%(14)$ & 764 & $1: 185$ & $1: 431$ \\
Total deaths (method 2) & 1632 & $43 \%(14)$ & 701 & $1: 123$ & $1: 285$ \\
\hline
\end{tabular}

a Based on an average annual birth cohort $\approx 200000$ (18). Cumulative risk per child by age 5 years $=1:(200000$ divided by mean events in 1 year among children $<5$ years $)$.

b 15\% of all deaths are reported through hospital discharge records $(16,17)$.

${ }^{c}$ Method $1=$ number of in-hospital deaths divided by 0.15 .

${ }^{\mathrm{d}}$ Method $2=$ (mortality among those $<5$ years old $) \times$ (birth cohort) $\times$ (proportion of deaths attributable to diarrhea). The mortality among those $<5$ years old is $48 / 1000$ live births $(17)$, the birth cohort is 200000 (18), and the proportion of deaths attributable to diarrhea is $17 \%$ (1).

of $30 \%$ for outpatients (15) and $43 \%$ for inpatients (13). We therefore estimated that 66600 of the consultations, 1888 of the hospitalizations, and 70 of the deaths each year would be related to $\mathrm{RV}$. We lacked data to correct for diarrhea treatment at private and semiprivate hospitals, clinics, pharmacies, and doctors' offices. Nonetheless, for an average birth cohort of approximately 200000 (range: 195000 to 210000 between 2000 and 2002 (18)), every child will require a consultation for diarrhea, 1:46 will be hospitalized, and 1:1 235 will die in a public hospital by their fifth birthday. Rotavirus-related risks would be 1:3 for consultation, 1:106 for hospitalization, and 1:2 857 for an in-hospital death.

We estimated the total number of diarrheal deaths, and subsequently rotavirus-related deaths, by two methods (Table 2). Since in-hospital deaths were estimated to represent only $15 \%$ of all deaths in Honduras (16), we directly extrapolated total deaths due to diarrhea from the total number of inhospital deaths by dividing the mean number of in-hospital deaths per year $(n=162)$ by 0.15 , resulting in 1080 deaths annually, for a risk of 1:185 for a diarrhea-related death by age 5 years. When we used an alternative method based on national mortality statistics for children $<5$ years old and estimators presented in a worldwide assess- ment for the fraction of diarrhea cases attributable to RV, we arrived at 1632 deaths and an approximate risk of 1:123 for diarrhea-related death by age 5 . For rotavirus-related deaths, given a $43 \%$ detection rate, the annual numbers of deaths from RV were estimated to be 464 with the first method and 701 with the second method. Therefore, the risks of a child dying of rotavirus-related diarrhea by age 5 years would be 1:431 with the first method and 1:285 with the second method.
Rates of diarrhea consultations were plotted for the eight health regions of the country (Figure 1). The lowest rates were in the central and northwestern regions. The highest rates were in the Atlantic coast and in the western health regions. The regions with high rates maintained their higher rates throughout the period studied.

The NSEFH 2001 survey yielded additional information on the prevalence of recent diarrheal illness and the

FIGURE 1. Map of Honduras, with mean annual rates of consulations for diarrhea among children $<5$ years by region, 2000-2004

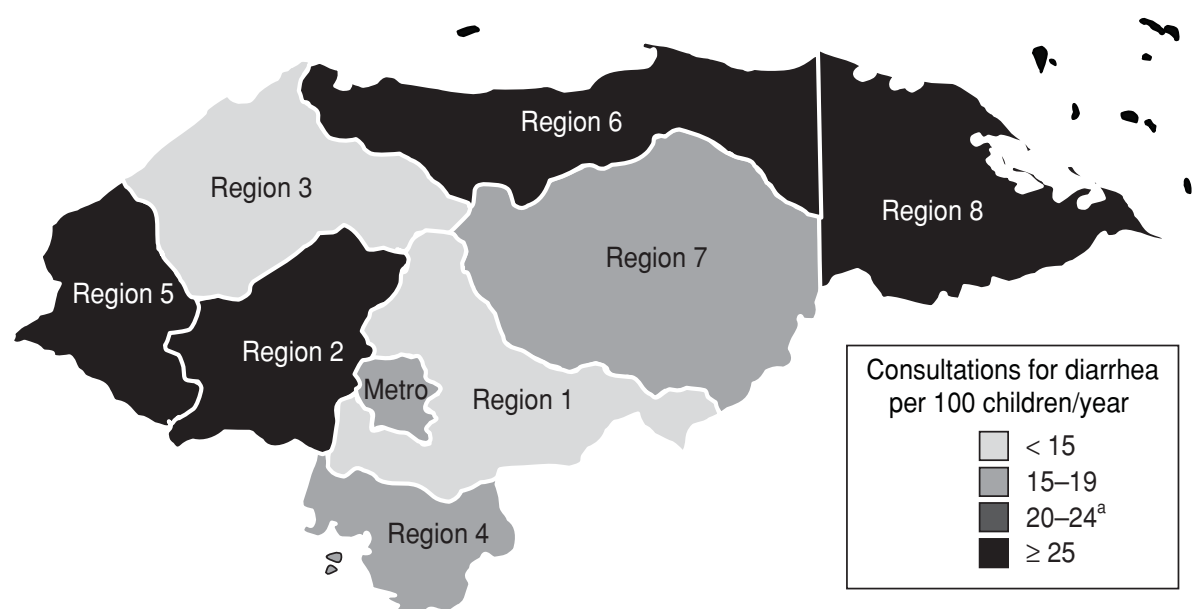

a No region reported 20-24 consultations for diarrhea/100 children/year. 
FIGURE 2. Trends over time in numbers of hospitalizations and consultations in Honduran public facilities due to diarrhea among children $<5$ years old, 2000 to 2004, with shaded areas corresponding to the "rotavirus season," a period when rotavirus has been documented to circulate in Honduras and neighboring countries, and diarrhea-related events rise to levels higher than the annual mean, then fall below the annual mean
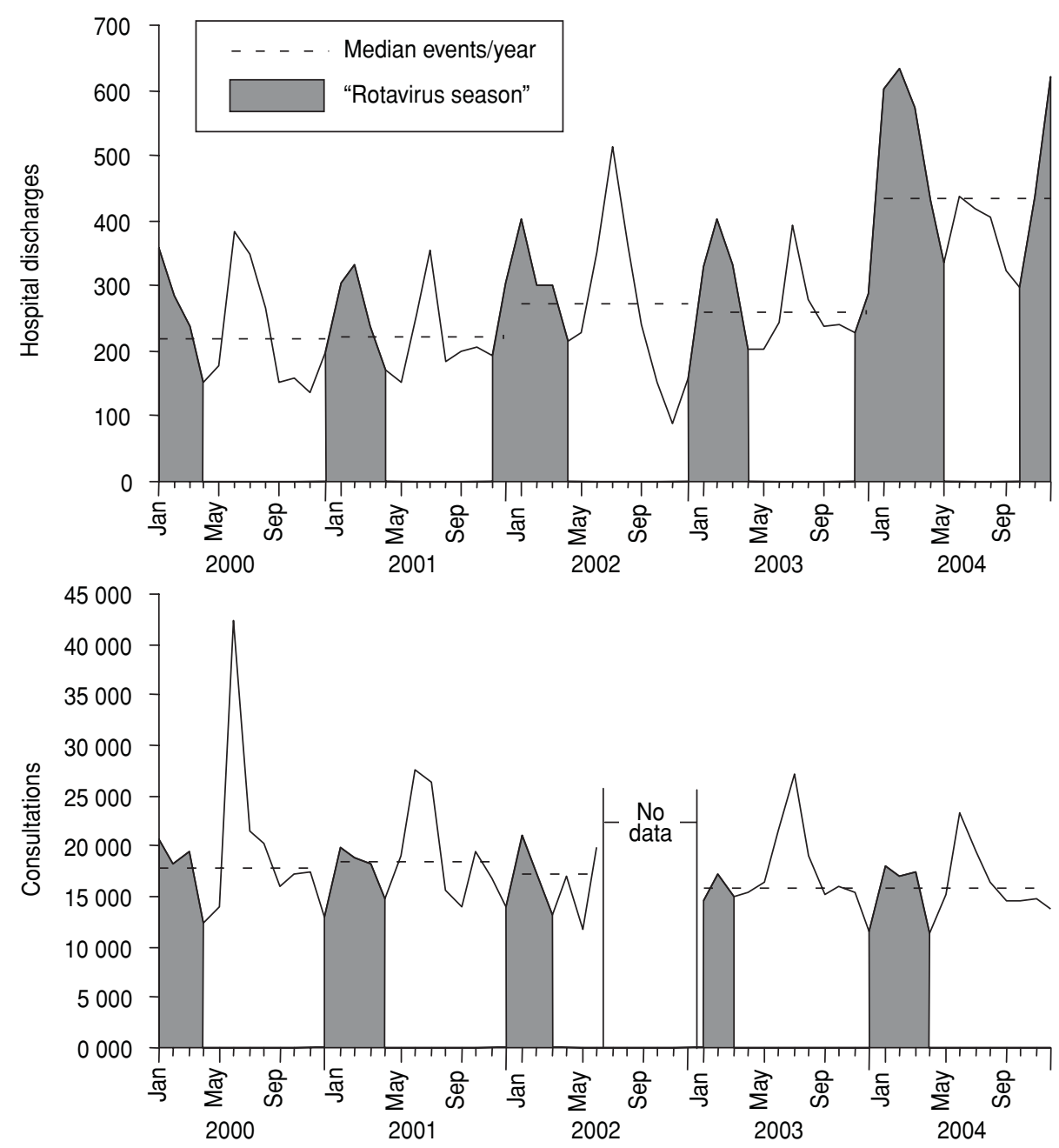

number of children who died of diarrhea. Among the 3936 children $<5$ years old whose health was surveyed through the interview of their mothers, a weighted $22 \%$ had acute diarrhea in the 15 days prior to the interview. (The methods of the weighting process are described elsewhere (12)). Of this $22 \%$, $49 \%$ were brought for consultation to a physician or clinic, $30 \%$ received oral rehydration solution, and $2 \%$ required hospitalization (12). Diarrhea and respiratory illnesses were the leading causes of death in the postneonatal period. Of 281 children who died from causes other than accidents, $50(18 \%)$ died of diarrhea. Nearly half of the $50(n=23)$ died during the RV season (November to March), with 12 (24\%) in the month of December alone. Most (80\%) deaths occurred outside of hospitals (34 at home, 10 in the hospital, and 6 elsewhere). Despite the mother recalling evidence of severe disease with dehydration (sunken eyes, depressed fontanelle, loss of skin turgor, and/or oliguria) in 47 of the children who died of diarrhea, $15 \%(n=7)$ were not brought for evaluation and care to a health care facility. Only $16 \%(n=8)$ of the children with a diarrhea-related death $(n=50)$ had been issued a death certificate.

Examination of the temporal trends of diarrhea-related events demonstrated that the monthly number of hospital discharges had two peaks, one in the early months of the year (January to April) and one in mid-year (June to August) (Figure 2). The findings of a community-based study in Honduras (13) suggest that the peak between January and April is likely attributable to RV, and could be termed 
TABLE 3. Risk estimates for events related to rotavirus (RV) per child by age 5 years in countries of the Americas and worldwide

\begin{tabular}{lcccc}
\hline & $\begin{array}{c}\text { Risk of RV-related } \\
\text { consultation by } \\
\text { age 5 }\end{array}$ & $\begin{array}{c}\text { Risk of RV-related } \\
\text { hospitalization by } \\
\text { age 5 }\end{array}$ & $\begin{array}{c}\text { Risk of RV-related } \\
\text { death by age 5 }\end{array}$ & $\begin{array}{c}\text { Per capita } \\
\text { gross national } \\
\text { income (US\$) }\end{array}$ \\
\hline Honduras $^{\text {b }}$ & $1: 3$ & $1: 106$ & $1: 285-431$ & 1030 \\
El Salvador (20) & $1: 7$ & $1: 56$ & $1: 531$ & 2350 \\
Peru (22) & $1: 9$ & $1: 20$ & $1: 375$ & 2360 \\
Argentina (23) & $1: 5$ & Not calculated & $1: 6937$ & 3720 \\
Venezuela (24) & $1: 24$ & $1: 72$ & Not calculated & 4020 \\
United States (25) & $1: 10$ & $1: 78$ & $1: 195000$ & 41400 \\
Worldwide (1) & $1: 5$ & $1: 65$ & $1: 293$ & Not applicable
\end{tabular}

a The data on per capita gross national income are from the World Bank (26)

${ }^{b}$ The risk estimates for Honduras given in the table do not correct for illness occurring outside of public health facilities.

the "RV season," while the peak between June and August is likely due to bacteria pathogens, as indicated by diarrhea surveillance among children in a neighboring country (20). This two-peak profile was more evident with hospital discharges than with consultations. The June-August peak for consultations was significantly larger than that in JanuaryApril, indicating that bacterial diarrheas remain a significant problem. However, for hospitalizations, the peaks were generally comparable, and in one case (the early peak of 2004) the early-year, January-April peak exceeded the mid-year, June-August peak. The number of in-hospital deaths per month was small and incomplete, limiting our ability to plot that. However, a curve with early- and mid-year peaks was observed, which lends additional evidence for the seasonal pattern of severe diarrhea in Honduras (data not shown).

\section{DISCUSSION}

Diarrhea is an important cause of illness and death in Honduras among children $<5$ years of age treated in public clinics and hospitals, causing more than 200000 consultations, 4000 hospitalizations, and 1000 deaths each year. This study provides baseline estimates of the burden of RV disease occurring each year: nearly 70000 consultations, almost 2000 hospitaliza- tions, and between 464 and 701 deaths among children $<5$ years old. The peaks in diarrhea-related consultations, hospitalizations, and deaths occurring between January and April suggest that RV is an important cause of severe disease early in the year (the "RV season"). Furthermore, while the mid-year and early-year peaks of diarrhea hospitalizations are similar in size, medical consultations are more numerous mid-year, suggesting that RV illnesses are more severe and more likely to result in hospitalization.

We were unable to assess the number of diarrheal illnesses treated at home or in private facilities. However, NSEFH 2001 data indicated that fewer than half of children with diarrhea are brought for consultation, and only one quarter received oral rehydration solution, highlighting that improvement in home and outpatient treatments could be instituted to prevent severe illness. Among fatal cases of diarrhea, 80\% died outside of hospitals, and $15 \%$ of children with diarrhea and signs of dehydration did not receive care at any facility. Furthermore, only $16 \%$ of the deaths were reported to civil authorities and issued death certificates.

The risk of RV-related events for a child in Honduras differs from the estimates published for several other countries in the Americas (Table 3). Not corrected for cases occurring outside of public hospitals in Honduras, for a Honduran child, the risk of hospitalization was lower than it was for a child in Argentina (23), El Salvador (20), Peru (22), the United States (25), and Venezuela (24). However, the risks for consultation and for death were higher in Honduras than in the other countries. All these other countries have per capita gross national incomes that are from 2 to 40 times the level in Honduras (26). The lower risk for hospitalization but higher risk for consultation and death for a child born in Honduras may reflect incomplete reporting of children visiting facilities other than the Government ones, or issues of access to health care services. This supports the finding by Parashar et al. (1) that RV illness has worse outcomes in poorer countries. Our estimates of the need for a clinic visit due to RV diarrhea in Honduras were comparable to the worldwide estimate of 1:5. However, our estimates were higher than the worldwide estimates for RV-related hospitalizations of 1:65 and for deaths of 1:293.

Our estimates of the burden of disease due to diarrheal illness have some real limitations. In addition, our estimates of the burden of RV are conservative and limited by available data, which are incomplete. We have not corrected for the proportion of children cared for outside of Government facilities. The lack of care at public health facilities for children with fatal illness, as indicated by the NSEFH 2001 findings, suggests that a segment of the population is not represented in the data flowing from public clinics and hospitals. However, our survey did not explore facility access.

The scarcity of information on RV in Honduras underscores the need for better data. The need is magnified because many countries of Latin America will likely consider the need for RV immunization in the near future, and the effectiveness of the vaccine cannot be measured without good baseline data and a mechanism to measure impact. A key factor in considering vaccine introduction in Honduras is the policy that most hospital and clinic care is provided at public facilities and paid for by the Government. Consequently, any decrease in severe RV illness leading to a reduced need for 
medical care will yield direct economic benefits for the OSH. A safe and effective $R V$ vaccine would prevent severe disease, including the proportion that now occurs outside public facilities. Based on the World Health Organization's generic protocols for hospitalbased surveillance to estimate the burden of rotavirus gastroenteritis in children (27), a sentinel hospital surveillance system has been established in Honduras to assess the prevalence of RV among children $<5$ years of age admitted at six hospitals throughout the country. These data, along with more targeted information on the economic cost of the disease, should improve the ability of local health policymakers to determine if introduction of a $R V$ vaccine is advisable, and to assess the price at which introduction of an $R V$ vaccine would be cost-effective and sustainable in the nation's program of childhood immunizations.
Acknowledgment. The findings and conclusions in this report are those of the authors, and they do not necessarily represent the views of the Centers for Disease Control and Prevention. The work presented in this paper was funded in part by unrestricted donations from the Rotavirus Vaccine Program of the Program for Appropriate Technologies in Health (PATH).

\section{REFERENCES}

1. Parashar UD, Hummelman EG, Bresee JS, Miller MA, Glass RI. Global illness and deaths caused by rotavirus disease in children. Emerg Infect Dis. 2003;9(5):565-72.

2. Glass RI, Bresee IS, Turcios R, Fischer TK, Parashar UD, Steele AD. Rotavirus vaccines: targeting the developing world. J Infect Dis. 2005;192(Suppl 1):S160-6.

3. Vesikari T, Matson DO, Dennehy P, Van Damme P, Santosharn M, Rodriguez Z, et al. Safety and efficacy of a pentavalent human bovine (WC3) reassortant rotavirus vaccine. N Engl J Med. 2006;354(1):23-33.

4. Dias Lopes A. Vacina do rotavírus entra no calendário oficial em dezembro. Estado de São Paulo 2005. September 14:A17.

5. Ruiz-Palacios GM, Pérez-Schael I, Velázquez FR, Abate H, Breuer T, Costa Clemens SA, et al. Safety and efficacy of an attenuated vaccine against severe gastroenteritis. $\mathrm{N}$ Engl J Med. 2006;354(1):11-22.

6. Braine T. Rotavirus vaccine introduction in Mexico sets precedent. Bull World Health Organ. 2005;83(3)167.

7. United States of America, Food and Drug Administration. FDA approves new vaccine to prevent rotavirus gastroenteritis in infants [news release]. Available from: http:// www.fda.gov/bbs/topics/news/2006/NEW 01307.html [Web page]. Accessed 9 February 2006.

8. Pan American Health Organization. Regional meeting for the Americas assesses progress against rotavirus. Rev Panam Salud Publica. 2004;15(1):66-70.

9. Palazzo M. Mamás felices con vacuna contra el rotavirus. Available from: http://www. lun.com/sociedad/Salud/detalle_noticia.asp ?cuerpo $=701 \&$ seccion $=800 \&$ subseccion $=$ $901 \&$ idnoticia $=$ C386138614295833 [Web page] . Accessed 20 September 2005.

10. Honduras, Secretaría de Salud, Departamento de Estadística, Unidad de Planeamiento y Evaluación de la Gestión. Salud en cifras: 19972001. Tegucigalpa: Secretaría de Salud; 2002

11. The Global Alliance for Vaccines \& Immunizations. 75 countries eligible for support.
Available from: http:/ / www.vaccinealliance. org/support_to_country/index.php [Web page]. Accessed 31 August 2004.

12. Honduras, Secretaría de Salud. Encuesta Nacional de Epidemiología y Salud Familiar. Informe final. Tegucigalpa: Secretaría de Salud; 2001.

13. Figueroa M, Padilla N, Gutierrez H. Rotavirus en las diarreas infantiles de Honduras. Rev Med Hondur. 1992;60(1):14-20.

14. Melgar-Cano R, Moncada W. Evaluación terapéutica de Saccharomyces boulardii en pacientes con diarrea líquida aguda: estudio de casos y controles. Publ Cient Postgrad Med. 2003;8:1-3.

15. Kane EM, Turcios RM, Arvay ML, Garcia S, Bresee JS, Glass RI. The epidemiology of rotavirus diarrhea in Latin America. Anticipating rotavirus vaccines. Rev Panam Salud Publica. 2004;16(6):371-7.

16. Pan American Health Organization. Regional Core Health Data Initiative. Country health profile 2002: Honduras. Available from: http://www.paho.org/English/DD/AIS/cp 340.htm [Web site]. Accessed 30 August 2004.

17. Pan American Health Organization, Health Analysis and Information Systems Area. Regional Core Health Data Initiative; Technical Health Information System. Estimated under5 mortality, Honduras, 2000-2004. Available from: http://www.paho.org/English/SHA/ coredata/tabulator/newTabulator.htm [Web site]. Accessed 30 August 2005.

18. World Bank. Database of gender statistics. Honduras, population age 0 male and female, 2000-2002. Available from: http://devdata. worldbank.org/genderstats/query/default. htm [Web site]. Accessed 31 August 2004

19. Mata L, Simhon A, Urrutia JJ, Kronmal RA. Natural history of rotavirus infection in the children of Santa Maria Cauque. Prog Food Nutr Sci. 1983;7(3-4):167-77.

20. Guardado JA, Clara WA, Turcios RM, Fuentes RA, Valencia D, Sandoval R, et al. Rotavirus in El Salvador: an outbreak, surveillance and estimates of disease burden, 2000-2002. Pediatr Infect Dis J. 2004;23(10 Suppl):S156-60.
21. Espinoza F, Paniagua M, Hallander H, Svensson L, Strannegard O. Rotavirus infections in young Nicaraguan children. Pediatr Infect Dis J. 1997;16(6):564-71.

22. Ehrenkranz P, Lanata CF, Penny ME, SalazarLindo E, Glass RI. Rotavirus diarrhea disease burden in Peru: the need for a rotavirus vaccine and its potential cost savings. Rev Panam Salud Publica. 2001;10(4):240-8.

23. Gómez JA, Nates S, De Castagnaro NR, Espul C, Borsa A, Glass RI. Anticipating rotavirus vaccines: review of epidemiologic studies of rotavirus diarrhea in Argentina. Rev Panam Salud Publica. 1998;3(2):69-78.

24. Salinas B, Gonzalez G, Gonzalez R, Escalona M, Materan M, Schael IP. Epidemiologic and clinical characteristics of rotavirus disease during five years of surveillance in Venezuela. Pediatr Infect Dis J. 2004;23(10 Suppl): S161-7.

25. Tucker AW, Haddix AC, Bresee JS, Holman RC, Parashar UD, Glass RI. Cost-effectiveness analysis of a rotavirus immunization program for the United States. JAMA. 1998;279(17): 1371-6.

26. World Bank. World Development Indicators Database: GNI per capita, 2004, Atlas method and PPP. Available from: http://www.world bank.org/data/databytopic/GNIPC.pdf [Web site]. Accessed 9 August 2005.

27. World Health Organization. Generic protocols for (i) hospital-based surveillance to estimate the burden of rotavirus gastroenteritis in children and (ii) a community-based survey on utilization of health case services for gastroenteritis in children. Geneva: WHO; 2002.

Manuscript received 5 December 2005. Revised version accepted for publication 26 June 2006. 
RESUMEN Objetivos. Estimar la carga anual por diarrea y por diarrea asociada con la infección por rotavirus (RV) en niños atendidos en clínicas y hospitales públicos de Honduras. Métodos. Los datos se obtuvieron a partir de los registros computarizados de todos los niños menores de 5 años atendidos por diarrea en clínicas y hospitales operados por la Secretaría de Salud de Honduras durante el período 2000-2004. Una revisión de los estudios realizados sobre RV en Honduras y los países vecinos ofreció estimados de las tasas de detección de RV en niños tratados por diarrea aguda hospitalizados o de forma ambulatoria. Con estos datos se estimó el número anual de casos de diarrea y de diarrea asociada con la infección por RV en Honduras, la incidencia acumulativa de diarrea y de diarrea asociada con la infección por RV en niños menores de 5 años y el número de muertes debido a RV en niños hospitalizados por diarrea. Resultados. Entre los años 2000 y 2004 se registraron medias anuales de 222000 visitas médicas, 4390 hospitalizaciones y 162 muertes hospitalarias por diarrea en niños menores de 5 años en instalaciones sanitarias públicas de Honduras. A partir de la revisión de la literatura científica relativa a Honduras y los países vecinos se estimó que $30 \%$ de los casos de diarrea atendidos ambulatoriamente y $43 \%$ de los hospitalizados podrían deberse a RV. En consecuencia, se estimó que 66600 visitas médicas ambulatorias, 1888 hospitalizaciones y 70 muertes hospitalarias de niños menores de 5 años pueden atribuirse a la infección por RV anualmente en Honduras. Por lo tanto, los riesgos de un niño en sus primeros 5 años de vida de asistir a una consulta, de ser hospitalizado y de morir en un hospital por diarrea son de 1:1, 1:46 y 1:1 235, respectivamente. Los riesgos asociados con la infección por RV son de 1:3, 1:106 y 1:2 857, respectivamente. Posiblemente, estos valores subestiman la carga real por diarrea en Honduras, ya que alrededor de $51 \%$ de los niños con diarrea aguda no reciben atención médica formal por esa enfermedad, $70 \%$ no reciben sales de rehidratación oral y $80 \%$ de las muertes por diarrea ocurren fuera de los hospitales.

Conclusiones. La diarrea es una importante causa de enfermedad en niños menores de 5 años en Honduras y la infección por RV es posiblemente su causa más frecuente. Estos estimados preliminares deben precisarse más para que los encargados de la planificación sanitaria en Honduras puedan tomar decisiones acerca de la aplicación de vacunas contra el RV en el futuro. En Honduras se estableció un programa basado en hospitales para la vigilancia de la infección por RV y para responder a esa necesidad.

Palabras clave Diarrea, infecciones por rotavirus, costos de la atención en salud, preescolar, lactante, recién nacido, Honduras.

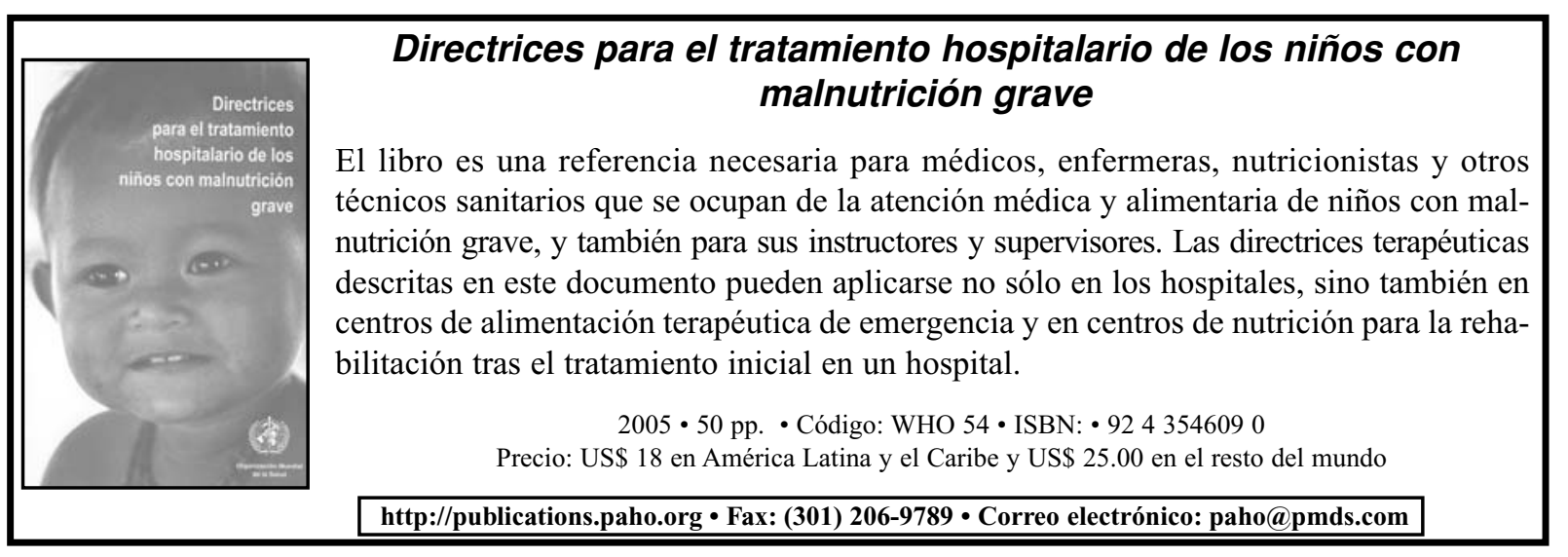

